\title{
小特集 液晶デバイスとテレビへの応用
}

\section{1. 液晶デバイスと動作原理}

\section{1. ま え がき}

近年, 半導体技術の進展にともなって情報機器の小 型・軽量化が急速に進み, これに対してディスプレイ の薄型・軽量化が強く望まれるようになってきた。す でにプラズマディスプレイの需要が急増しているが, 今後の高解像度化, カラー化の要求に対して, 液晶デ イスプレイ (LCD) は有力候補のひとつと考えられる. 小型のものではすでに高品位のフルカラーディスプレ イが開発され，液晶テレビとして実用化されている． ごく最近では中型ディスプレイの分野でも急ピッチで その大容量・高品質化が進められている．また，大型 ディスプレイの分野では投射型カラーディスプレイが 開発されつつある。このような状況をふまえて，本論

\section{『液晶デバイスとテレビへの応用』} 小特集の企画について

表示デバイスの平板化に熱い視線が集中してい る。なかでも，とりわけ液晶デバイスについては 産学を問わず，随所で活発に研究・開発が展開さ れており，躍進的進歩が著しい。高解像度のコン ピュータディスプレイや，鮮明なカラーポケット 液晶テレビの出現をみると，まさにそういう時代 だと実感できる。

そこで，本号では液晶デバイスを取り上げ，特 にテレビ・画像に関する応用に着目して小特集を 編んだ。最新技術を理解するための動作原理，高 画質化への新しい道を拓いた駆動方式，商品とし ての地位も固まってきた液晶テレビへの応用，液 晶の長所を生かした各種画像応用，CRT なみの 高画質を目指す将来展望について，最新の話題を 取り上げている。

この小特集は倉重光宏 (幹事)，江藤良純（幹 事)，古角尚之 (幹事) が企画編集を担当した。

\section{正会員 内 田 龍 男 ${ }^{\dagger}$}

文ではまず，これら各種のディスプレイの基礎となる 種々の液晶表示モードの動作と特徴を概説する。つい で, LCD の大容量化，カラー化の現状を述べるとと もに, 液晶デバイスの将来動向を展望する.

\section{LCD の種類と基本動作}

LCD には，多数の表示モードが提案されているが， そのうちで現在主として研究あるいは実用されている ものを図 1 に示す．以下，これらについて動作と特徵 を概説する。

\section{1 ねじれネマティックモード（TN*モード）}

本論文では，図 2(a)のようにねじれ分子構造を有 し，これを 2 枚の偏光子で㣣んだ構造のものをまとめ て広義のねじれマティックモード（TN*モード）と呼 ぶことにする。

$\mathrm{TN}^{*}$ モードの基本的なものは, $\mathrm{Schadt}^{1)}$ によって 提案された，ねじれ角 $\phi_{t}$ が $90^{\circ}$ のものであり，これ を狭義のねじれネマティックモード (TN モード) と呼

図 1 LCDの主要な表示モード

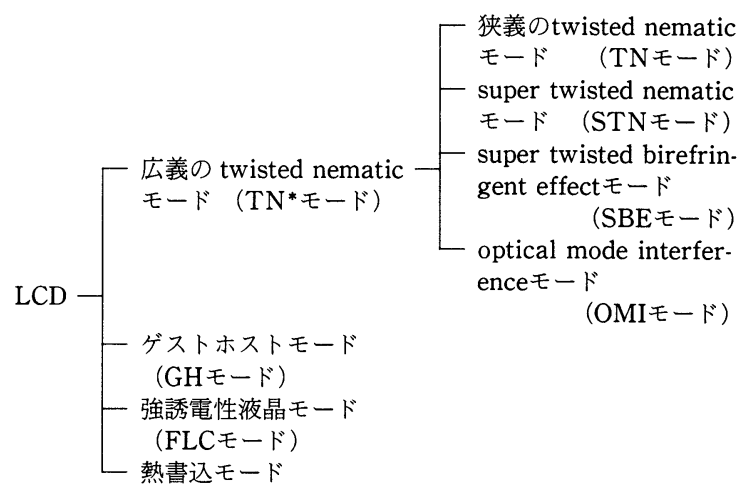

$\dagger$ 東北大学 工学部

"Liquid Crystal Devices and Their Fundamentals of Operation" by Tatsuo Uchida(Faculty of Engineering, Tohoku Vniversity, Sendai) 


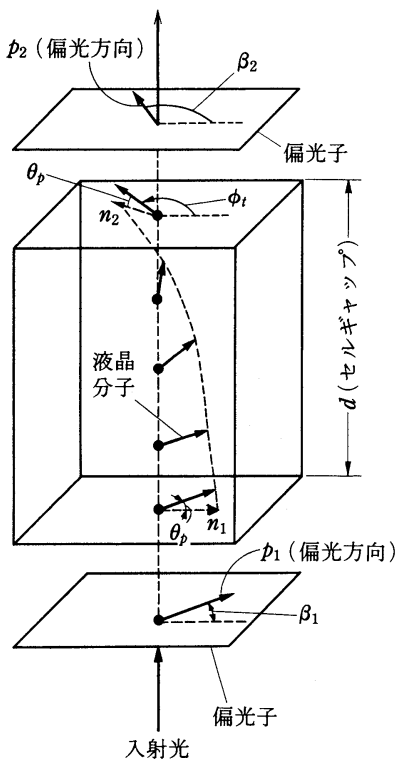

（a）液晶の分子配向と 偏光子の方向 (b) $\mathrm{TN}$ セ

$\left(\Delta n \cdot d=1.0 \mu \mathrm{m}, \theta_{p} \approx 1^{\circ}\right.$ $\phi_{t}=90^{\circ}, \beta_{1}=\beta_{2}=0^{\circ}$ )

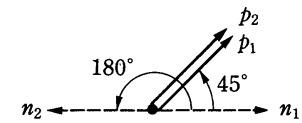

(c) STN セル

$\left(\Delta n \cdot d=0.95 \mu \mathrm{m}, \theta_{p} \approx 1^{\circ}\right.$

$\phi_{t}=180^{\circ}, \beta_{1}=45^{\circ}, \beta_{2}=180^{\circ}$ )

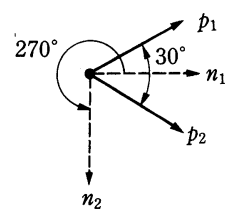

(d) SBE セル

$\left(\Delta n \cdot d=0.9 \mu \mathrm{m}, \theta_{p} \approx 20^{\circ}\right.$ $\phi_{t}=270^{\circ}, \beta_{1}=-\beta_{2}=30^{\circ}$ )

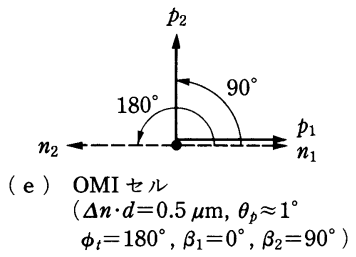

行であれば，この逆になる)。このセルは駆重 電圧が低いこと，高いコントラストが得られ： こと，マルチプレックス駆動特性が良いこと： どの特長があるために，現在最も広く実用され ている.

ところで, TN モードでは 2 枚の偏光子の们 光方向を平行にしてブラックシャッタとしてF いる方式が自動車用ディスプレイ，オーディス 用ディスプレイ，後述のフルカラーディスプレ イなどに応用されている。この場合，一般に ックライトと組合せて透過型として用いられ气 が，これには off 状態の光のもれをできるだけ 少なくして高いコントラストを得る必要がま る．そのためにはまず, 偏光子の偏光度 $V(I$ は, 偏光子の偏光軸に平行および垂直な振動芷 をもつ光の透過率を $T_{1 /}$ および $T_{\perp}$ とすると $V=100\left(T_{/ /}-T_{\perp} /\left(T_{/ /}+T_{\perp}\right)\right.$ で定義される $)$ を できるだけ高くする必要があるが，液晶の設言 条件を最適化しないと, 偏光子の偏光度を高く してもコントラストはある程度で飽和してしま $う^{2)}$.これは, 前述の入射偏光の $90^{\circ}$ の回転力 実際には正確に行われず，セルを出た光は楕P 偏光となるためである．その楕円率と長軸方后 は $\Delta n \cdot d / \lambda(\Delta n$ は液晶材料の複屈折率であり 分子に平行な方向の屈折率と垂直な方向のそね との差, $d$ はセルギャップ, $\lambda$ は光の波長) に 依存し，そのために一部の光は第 2 の偏光子を 通過してしまう。これが off 状態における光の もれに対応し，偏光子を理想的なもの $(V=101$ \%) とすると，その強度は $\Delta n \cdot d / \lambda$ の関数とし て図4のようになる ${ }^{3)}$ 。なお, 図で, $\Delta n \cdot d / \lambda=$ $\left(m^{2}-1 / 4\right)^{1 / 2}(m$ は整数) の場合には, 出射光 が直線偏光となり，その偏光方向は入射光のそ れに対してちょうど $90^{\circ}$ 回転した状態となる ので透過率は零となる．ただし，実際のセルて は偏光子が理想的ではないので, この場合のも れ光の強度は, 2 枚の偏光子の偏光方向を互し: に直交させた場合の透過率 $T$ (cross) に等しく なる．この強度は偏光子の明るさを $T_{p}=\left(T_{\text {， }}\right.$ $\left.\left.+T_{\perp}\right) / 2\right)$, 偏光度を上述のように $V$ とする と,

$T($ cross $)=4 T_{p}^{2}(100-V) /(100+V)$

ぶことにする，TN セルの動作は，図 3 に示すよう に, off 状態では入射偏光が $90^{\circ}$ 回転し, on 状態では 回転せずに透過する.したがって，2枚の偏光子の偏 光方向が直交していれば, off 状態では光が透過, on 状態では遮断されることになる（偏光方向が互いに平

で表される.一方, on 状態の透過率 $T_{\text {on }}$ は, $2 T_{p}{ }^{2}$ と なる。したがって，なるべく明るくて偏光度の高い偏 光子が必要である. 偏光子の明るさと偏光度の関係は 一般にトレードオフの関係にあるが, 最近この両方を 


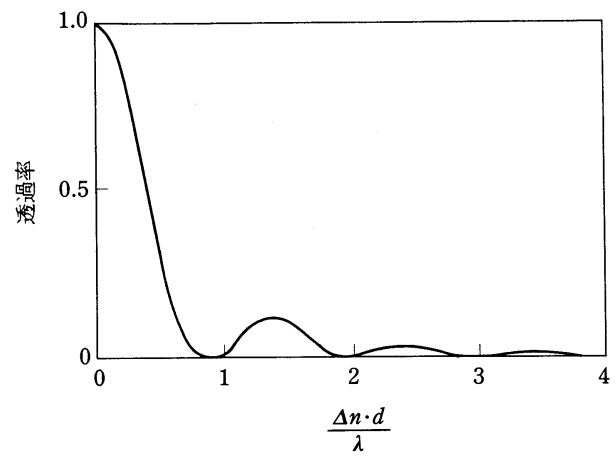

図 $4 \mathrm{TN}$ セルにおける off 状態の光のもれと $\Delta n \cdot d /$ $\lambda$ の関係 (TN セルの 2 枚の偏光子は偏光度 100 \%の理想的なものとし, 透過率は液晶の厚さを 零とした場合の值で規格化してある)

言くした高性能の偏光子が開発され, 実用され始めて 小る4).

一方, 最近マトリクス LCD の大容量化が進んでい るが, 後述の直接マトリクス LCD の大容量化には閾 寺性の急峻な液晶セルが必要である.TN モードで急 夋な閾特性を得るためには, プレティルト角 $\theta_{p}$ (基板 表面に扔ける液晶分子の表面に対する傾斜角)，およ ベ, 弾性定数比 $k_{33} / k_{11}\left(k_{33}, k_{11}\right.$ はそれぞれベンドおよ ベスプレーの弾性定数）をできるだけ小さくする必要 ぶある．そのために多くの努力が行われ， $\theta_{p}$ は $1^{\circ}$ 程 芠, $k_{33} / k_{11}$ は 0.65 程度まで減少させたものが開発さ 几ているが, 表示品位を落さずに走査線数を増加させ 寻る限界は現状では 60 70 程度にとどまっている(た だし，一般には画面を上下に分割する上下分割駆動法 が用いられるので，見かけの走查線数はこの 2 倍の (20１40本となる).これに対して, 最近ねじれ角 $p_{t}$ を大きくすることによって，閾特性の急峻さを大 湢に改善できることが見い出され，大容量化が急速に 售み始めた。

まず，ねじれ角を $180 〜 200^{\circ}$ 程度にした super :wisted nematic モード（STN モード, 図 2(c)) が 開発され ${ }^{5)}$, 上下分割駆動法を用い見かけの走査線数 を 400 本（実際の走査線数は 200 本）としたディスプ レイが実用化され始めている．このセルでは，TN モ 一ドとは逆に $k_{33} / k_{11}$ が大きいほど閾特性が鋭くなる ため, その種の液晶材料の開発が活発に行われてお り, 現在 $1.6 \sim 1.8$ 程度の值が達成されている.さら に、ねじれ角を $270^{\circ}$ と大きくした super twisted jirefringent effect モード (SBEモード, 図 2(d)) で は, 実際の走查線数を $400 \sim 600$ 本程度まで増加させ 得ることが示された ${ }^{6)}$.
ただしSBEセルの場合は, らせん軸が傾く別の配 向変形モードの発生を防ぐために, プレティルト角を $20^{\circ}$ 程度と大きくする必要がある。それには斜蒸着な どの量産化に適さない技術を導入しなければならず， そのために現在のところ実用化は進んでいない。この 問題を解決するために，現在大きいプレティルト角の 得られる表面配向剤の開発が活発に行われている.

なお，STN およびSBEモードでは図 2(c)，（d) に示すように，壁面の分子配向方向と偏光方向をずら してあるために入射偏光は分子の配向方向に平行およ び垂直な偏光面をもつ光 (それぞれ異常光および常光) に分解される。これらは，液晶中の伝搬速度が異なる ので，上側の偏光子を通過する際に互いに干渉するこ とになる(複屈折による干渉と呼ばれる)，この干渉条 件は, 分子配向のわずかな変化でも大きく変化するの で，これが閾特性をいっそう急峻にしている。しか し, 同時にこの干渉の効果で off 状態が着色するとい う問題が生じ，これがコントラストの低下およびマル チカラー化への障害を招いている．また，セルギャッ プのばらつきが干渉色の変化として敏感に反映される ので, 精度 $\pm 0.1 \mu \mathrm{m}$ ないし $\pm 0.2 \mu \mathrm{m}$ 以下の精密なセ ルギャップの制御が必要とされ，これが製造の歩留り を著しく低下させる原因となっている．

これらの問題を解決したのが optical mode interference モード (OMI モード, 図 2(e ) ) である7).こ のモードのセルでは, $\Delta n \cdot d$ の值を小さくし, 楕円偏 光モードにして波長依存性を小さくすることによって off 状態がほぼ無彩色となるようにしている。これに よって表示の見やすさが向上し, マルチカラー化の可 能性が得られると共に, セルギャップの制御精度が緩 和された。一方, 問題点は, STN セルやSBEセル と比較して閾特性の鋭さが劣ること, 透過率が低いこ となどである。

これらの問題に対して, ごく最近, OMI セル（また はSTN セル）に，ねじれ方向を逆転させた液晶セル を重ねて複屈折効果を補償させ, 高コントラストの白 黒表示の LCD を実現する方式が考案された.コント ラストの向上は, 主として黒レベルの透過率を低下さ せることによって実現しているが，これによって基本 的には走査線数を増加させても，かなり高いコントラ ストを維持することができる，ただし，走查線数の増 加と共に白レベルの透過率は減少するので，それを補 うためにバックライトが必要となる。いずれにして も, この種のディスプレイによって, 高品位の大容量 カラーマトリクス LCD が大きく前進するものと期待 される。 


\section{2 ゲストホストモード}

ゲストホストモード ( $\mathrm{GH}$ モード) は, 液晶中に添加 した 2 色性色素の吸収係数の異方性を利用して表示を 行うものである。すなわち，液晶によって配向させた 色素は, 電界の印加によって配向を変化させることが できるので，それによってセルの着色濃度を変化させ ることができる. 各種の方式が提案されているが，そ のうち主要なものを図 5 に示す。いずれも閾特性がな だらかであるためにマルチプレックス駆動ができず， そのために TN セルほど広く使われていない。しか し, 明るさや広視角が要求される自動車用ディスプレ イや $\mathrm{OA}$ 機器の一部には 2 層型 $\mathrm{GH}$ モード8) あるいは White-Taylar 型 GH モードが，また，オーディオ機 器には Heilmeier 型 GH モードが使われている。ま た，後述のアクティブマトリクス LCD では閾特性の 急峻さを必要としないので, 視野角が広くて構造が比 較的簡単な Heilmeier 型 GH モードの採用が検討さ れている。なお，最近 2 色性色素に関して，より高い 2 色性比を得るための分子形状の設計指針が明確にさ れており ${ }^{11)}$, 表示品位のいっそうの向上が期待され る。

\section{3 強誘電性液晶モード（FLC モード）}

カイラルスメクティック C と呼ばれる液晶は強誘 電性を示す液晶として近年高い関心を集めている。こ れは, ギャップ 1〜2 $\mu \mathrm{m}$ のセルを作ると $10 \mu \mathrm{s}$ のオ ーダの高速応答性とメモリー効果が得られるためであ る ${ }^{12)}$.すなわち，ラビングなどの適当な配向処理を施 して図6(a)のように均一に配向させたセルでは，乡 子のダイポールモーメントが 1 方向に揃っており， : れに反対向きの電界を印加すると ( b ) 図のように配「 方向がいっせいに反転し, 電界除去後もそのまま蓄禾 される。したがって, 図のように 2 枚の偏光子で㣣, でおけば明暗の切り換えが可能である．ただし，これ で高いコントラストを得るためには，(a)図と（b)E の状態の分子配向方向が $45^{\circ}$ をなすような液晶材料? 選ぶこと， $\Delta n \cdot d$ を $0.26 \mu \mathrm{m}$ 程度に設定すること 。 どが必要とされる．この方式は，上述のようなユニー クな特長を持つ一方で, 次のような多くの問題点をき えている.

（1）セル作成の段階で配向欠陥が生じやすく, 年

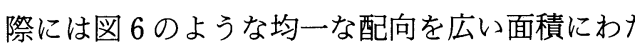
って実現するのは容易ではない。

（2）機械的ショックや熱膨張による液晶の流動に よって配向が乱れると，自発的に回復する作用? 持たない.

（3）広い面積にわたって 1～2 $\mu \mathrm{m}$ の均一なセルシ ヤップに制御すること，およびこの狭いセルギ: ップに液晶を導入することが容易ではない.

(4) 後述する逐次書込み型の大容量ディスプレ, を作製するには $10 \mu \mathrm{s}$ 以下の高速応答が要求され るが，そのためには液晶の応答速度をさらに向_ させること, 面抵抗 $10 \Omega$ 以下の透明電極を開严 すること，瞬時的にかなり大きい電流を流すこる のできる駆動回路を必要とする.

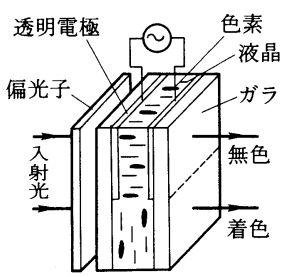

(a) Heilmeier 型

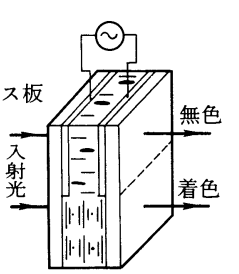

(b) White-Taylor 型

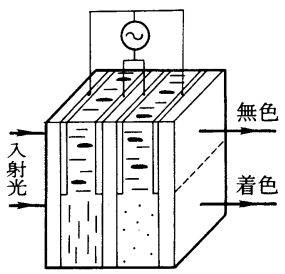

(c) 2 層型

図 $5 \mathrm{GH}$ モードの液晶ディスプレイ（セルの上半分は電圧印加状態, 下半分は無印加状態)

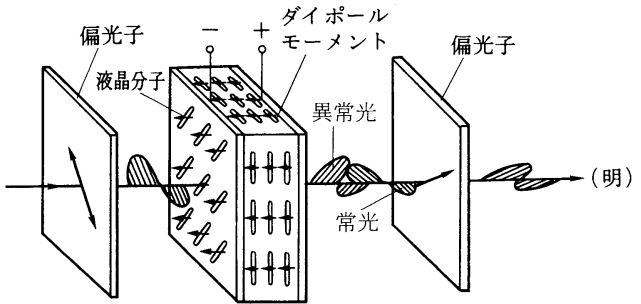

(a) 書込み状態

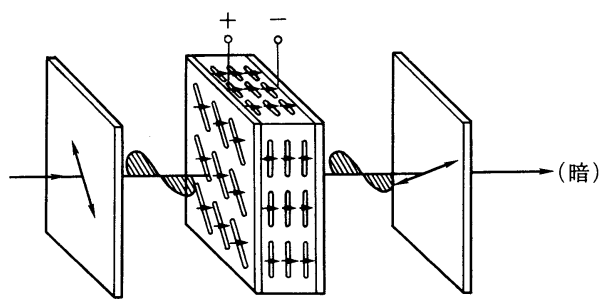

（b）消去状態

図 6 強誘電性液晶モード 


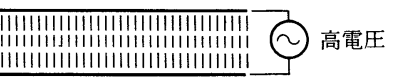

(a) 全面消去

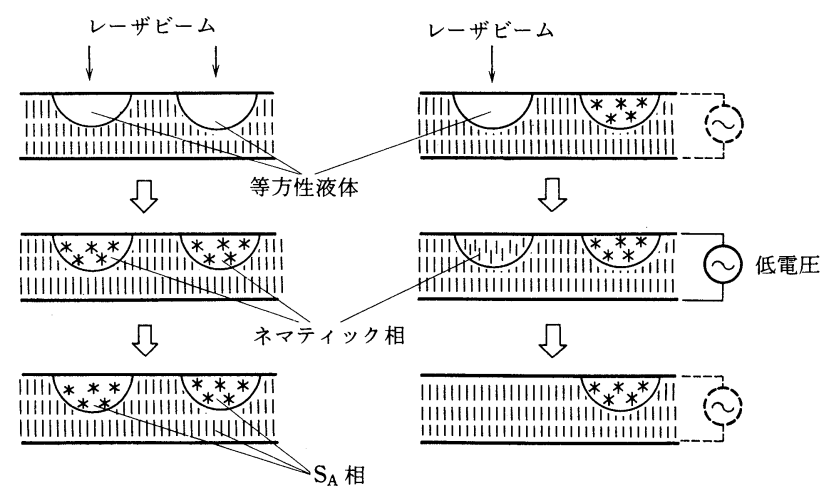

(b) 書込み

(c) 部分消去

図 7 レーザ書込み方式の動作（』はレーザビーム照射部分の冷却過程を示す）

このような問題がすべて解決されるためには, まだ 一ばらく時間がかかるものと考えられる.しかし, 最 I( 1 )や ( 2 )の問題に対する解决のきざしも見えはじ つており, いずれ近い将来, ディスプレイを初めとし :, オプトエレクトロニクスの分野で重要なデバイス :なり得る可能性がある.

\section{4 熱書込みモード}

スメクティック $\mathrm{A}$ (室温)ーネマティックー等方性液 上 (数 $10^{\circ} \mathrm{C}$ ) の相系列を持ち, 正の誘電異方性を示す 多晶を用いると熱書込み型のセルを構成することがで らる．特にレーザビームの熱を利用して書込みを行う 方式の動作原理を図 7 に示す ${ }^{13)}$.

すなわち, まずスメクティック $\mathrm{A}$ 相で全面に高電 こを印加すると基板に垂直な配向 ( a )が得られる（全 了消去).これにレンズ系で絞ったレーザビームを照 扎て等方性状態まで昇温した後, ビームを除去して 晶を急冷させると図 7(b)のようにスメクティック 相で乱れた配向 (focal conic 組織) が形成される (書 こみ).したがって，ビームを走査することによって 幅 $10 \mu \mathrm{m}$ 程度の微細なパターンを書込むことがで :る.しかもスメクティック $\mathrm{A}$ 相は粘度が高いので, .の表示パターンは数カ月以上蓄積される.パネル全 うに低電圧を印加しながらレーザビームを照射すると 㑢過程でネマティック相を通過する際, 図 7(c)の うに均一配向に戻すことができる (部分消去).

この種のディスプレイは一般にスクリーン上に拡大 写され，大画面の高解像度ディスプレイとして応用 検討されている.

\section{3. マトリクス LCD の駆動方式}

白黒の数字表示あるいは簡単なドットマトリクスの LCD はすでに広く実用されているが, 最近の LCDの 研究開発の中心のひとつとしてマトリクス LCD の大 容量化の問題がある.そこで本節では, この問題につ いて簡単な説明を加える。

マトリクス LCD の駆動方式を分類すると図 8 のよ うになる．図でスタティック方式は各画素から 1 本ず つリード線を取り出して駆動するものであり, 高品位 の表示が得られるのが特長である。しかし，リード線 と駆動回路の数が膨大になるために画素数 $8 \times 64$, 大 きさ $58 \times 460 \mathrm{~mm}^{2}$, あるいは画素数 $40 \times 52 \times 3$ 色, 大きさ $200 \times 260 \mathrm{~mm}^{2}$ 程度のモジュールを多数並べて 大画面ディスプレイを構成する方式がとられてい $3^{14) 15)}$. 後述のマイクロカラーフィルタ方式を用いた もので, $3 \times 12 \mathrm{~m}^{2}$ の超大型ディスプレイが試作され ている.

単純マトリスク方式は，LCDの 2 枚の基板にそれ ぞれ $\mathrm{X}$ および $\mathrm{Y}$ 方向のストライプ電極を構成し，そ の交点を画素とするものである．X 電極を 1 ライン ずつ順次走査し, 各ラインに対応する信号電圧を $\mathrm{Y}$ 電極からいっせいに印加することによって任意の画像 の表示が行われる。ここで, 現在広く用いられている 累積応答型は, 1 ラインの選択時間を液晶の応答時間 より短く設定したものである。したがって, 図 9 に示 すように, 数回の走査を繰り返した後に透過率が定常 状態 $\left(T_{\text {on }}\right.$ または $\left.T_{\text {off }}\right)$ に達することになる。この場合 の透過率 $T_{\text {on }}$ または $T_{\text {off }}$ は, (a)図の電圧波形に対 
応する実効電圧 $\left((\mathrm{b})\right.$ 図の $V_{\text {on }}$ または $\left.V_{\text {off }}\right)$ で決まる。 したがって, 走查線数が増すほど $V_{\text {on }}$ と $V_{\text {off }}$ の比が 小さくなり，コントラストが取りにくくなる。このた めに, 大容量のマトリクス LCDには $V_{\text {on }}$ と $V_{\text {off }}$ の比 が小さくても光学特性の差が大きくとれる液晶, すな わち闇特性の急峻な液晶が要求されることになる.

一方, 逐時書込み型の直接マトリクス方式は, 図 10 に示すように選択時間を液晶の応答時間より長く したものである.したがって, この方式は少なくとも フレーム時間より長いメモリー性を持つ液晶でなけれ ば適用することができない。この方式の特長は走查電 極数を増やしてもコントラストが低下しないことであ る.一方, 問題点は, 1 画面の書込みに少なくとも液 晶の応答時間 $\tau$ と走査線数 $N$ の積の時間を要するの で, 表示容量の増加とともに画面書換えの時間が長く なることである．

このような理由で, 本方式は応答速度の早い強誘電 性液晶に採用されているが, 前述のようにその応答速 度はまだ充分とはいえない状態である。

アクティブマトリスク方式には, 各画素ごとに薄膜 トランジスタを付けた TFT 型と非線型ダイオードを 付けたダイオード型がある．このうち，TFT 型は， そのスイッチング特性と画素容量を利用して, 選択期

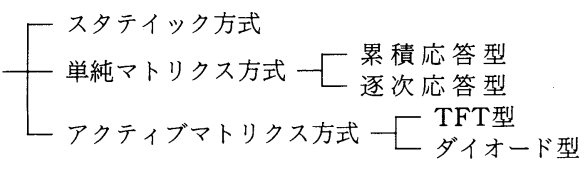

図 8 大容量ドットマトリクス LCD の各種駆動方式

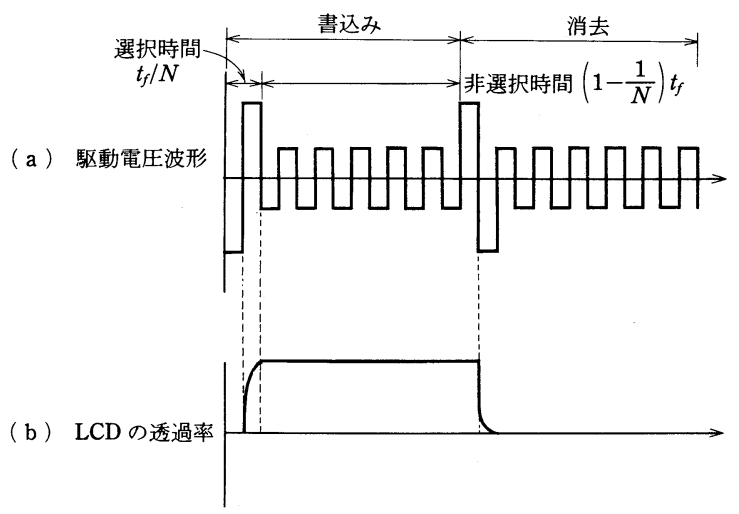

図 10 逐次応答型 LCD の動作（強誘電液晶セルの例）

間に印加された電圧を次の走査まで保持するものであ る. 大容量で高いコントラストおよび中間調を容易に 得ることができるという特長があり, 高品位の液晶テ レビとして実用されている。製造プロセスが複雑であ るために, 画面サイズの増加と共に歩留りが指数関数 的に低下する問題があり, 今後の課題とされている.

ダイオード型のアクティブマトリスク方式は, 製造 プロセスが TFT 型より簡単であり, 駆動波型を適当 に設計すれば TFT 型と類似した高い表示品位が得ら れる。しかし, 非線形素子と画素容量との直列回路の 動作は複雑で, あらゆる表示パターンに対して TFT のような理想的な電圧駆動条件を得ることは容易では ない。 また，素子のばらつきが表示特性に直接影響を 及ぼすために, 特性をかなり厳密に制御しなければな らない。したがって，TFT 型と比較していずれが有

(a)

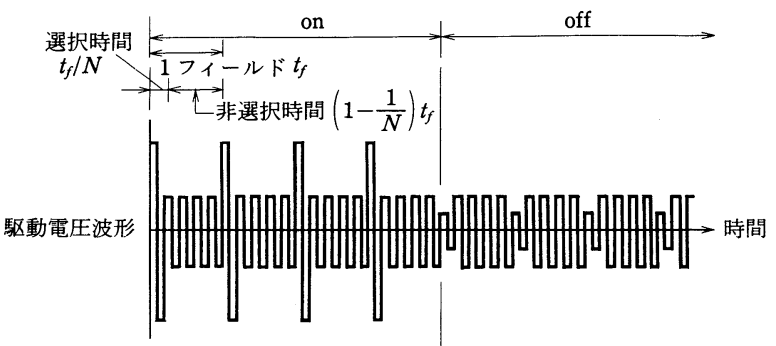

(b ） 実効值電圧

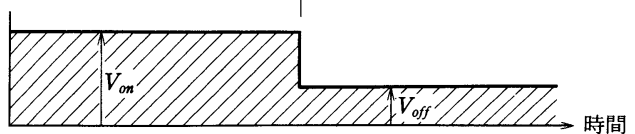

(c) LCD の透過率

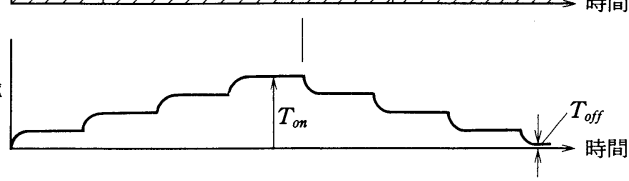

図 9 累積応答型 LCD の動作 
利であるかは一概には決められない。

\section{4. カラ $-\mathrm{L}$ C D}

LCD をカラー化する方式を分類すると図 11 のよう になる。

ここで複届折方式は ECB セルの常光と異常光の干 渉によってカラー表示を行うものであり ${ }^{16)}$ ，印加電圧 によって干渉色を連続的に変化させることができる. しかし, この干渉色は観察方向や温度の変化によって 敏感に変化するために使用条件が難しく，実用化には 至っていない。

減法混色方式の代表的なものとしては，GH セルを 積層したもの ${ }^{17)}$ をあ゙ることができる．前述のよう に，ゲストホスト方式は大容量の単純マトリクスには 向かないので，スタティック方式またはアクティブマ トリクス方式を採用する必要がある，画素の大きさを 比較的大きくして大画面にする場合はスタティック方 式が適している ${ }^{15)}$. しかし，高解像度のディスプレイ では斜めから観察した場合の色ずれが問題となる。こ の問題を解決する方法として, プラスチック基板 ${ }^{18)}$ やカプセル化したゲストホスト液晶 ${ }^{19)}$ の採用が考え られる、ただし, 高解像度の $\mathrm{GH}$ セルではアクティ ブマトリクス方式の適用を要するものと考えられるの で，この方式ではプラスチック基板上へのアクティブ 素子の形成技術の開発が重要な課題となろう.

透影型の加法混色方式は，3 枚の LCD の表示パ夕 ーンを赤, 緑, 青のフィルタを通してスクリーン上に 重ねて投影するものである。レーザ書込み型 $\mathrm{LCD}^{13)}$ およびアクティブマトリクス $\mathrm{LCD}^{20)}$ ですでにこの方 式を応用したカラーディスプレイが試作されている。 特に投射型のアクティブマトリクス LCD は高輝度の 大型カラーテレビとして期待される.

時分割型の加法混色方式は 1 フィールドごとに光源 の色を赤, 緑, 青と順次切り換えるものである ${ }^{21)}$.し たがって，逐次書込み型の駆動方式が適しているが， フリッカを生じさせないために高速応答性の液晶が要 求される. 強誘電性が有力な候補であるが, 前述のモ

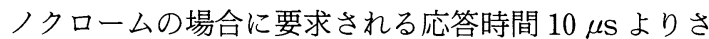
らに 3 倍の速い応答速度が要求されるため, この実現 にはさらに年月を要するものと考えられる。なお，強 誘電性液晶とアクティブマトリクス方式を組合せれば 1フィールドの書込み時間を大幅に短縮できる可能性 があり，時分割型を実現できる可能性は少なくない．

マイクロカラーフィルタ型の加法混色方式は，マト リクス LCD の各画素ごとに赤, 緑, 青のカラーフィ ルタを微細加工して付けたものである ${ }^{22)}$. 構造が簡単

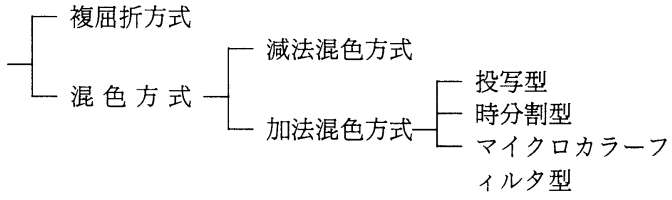

図 11 カラーLCDの方式

であり，良好な表示カラーが得られるために，スタテ イック方式, 単純マトリクス方式, アクティブマトリ クス方式などと組合せてすでにかなり実用化が進んで いる，一方，この方式の問題点は，光の利用効率が悪 く, 液晶パネル全体の透過率が数\%と暗いために，か なり明るいバックライトを必要とすることである。こ の問題を解決するために, 相転移型のゲストホスト方 式を用いた明るい反射型マルチカラー LCD の検討も 行われており，最近実用レベルの明るさが得られるに 至っている ${ }^{23)}$.

\section{5. 液晶デバイスの現状と将来動向}

すでに述べてきたように，液晶の表示モードおよび 駆動方法には多くの方式があり，それらを組合せるこ とによって，特性を幅広く選択することができる。な かでも，TN*モードを用いた単純マトリクス LCD は構造が簡単で製造が容易であるために研究開発が活 発に行われており，最近大型化，大容量化が急速に進 み始めている。早晚高コントラストのマルチカラー LCD として実用化が進むものと考えられる．ただし， 大容量のものは一般に応答速度がやや遅くなると共 に, ヒステリシス特性を示すので, 中間調表示や動画 表示は困難であろうと考えられる。

一方，TN モードを用いたアクティブマトリクス LCD は，小型・高品位のフルカラーディスプレイとし て数年前から開発が続けられている．現状ではこの大 型化は容易ではないが，いずれ画素数 $1000 \times 1000 \times 3$ 色, 対角 12 インチ程度のものも, ある程度の歩留り で製造できるようになろうと考えられる。さらに，大 型のディスプレイとしては，アクティブマトリクスを 用いた投影型ディスプレイが有望であるが，強力な光 源の採用と光の利用効率の向上をはかることにより， 高輝度の大画面カラーディスプレイが実現できるもの と考えられる。これに関連して，HDTV 用ディスプ レイへの応用も期待されるが，このためには，超微細

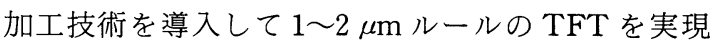
し, 高解像度化と供に高開口率化をはかる必要があろ う.

ところで，液晶の用途はこれまで主としてディスプ レイデバイスが中心であったが，液晶のもつユニーク 
な光学特性を応用したセンサデバイスや光演算デバイ スなどのオプトエレクトロニクスデバイスとしての用 途も開発され始めている. 今後, このオプトエレクト ロニクスの分野は, マイクロエレクトロニクスと共に 大きく発展して行くものと思われるが, これに関連し て低電圧・低電流動作の液晶デバイスの役割はますま す重要になっていくものと考えられる.

(昭和 62 年 9 月 14 日受付)

\section{〔参 考 文 献〕}

1) M. Shadt and W. Helfrich: "Voltage Dependent Optical Activity of a Twisted Nematic Liquid Crystal", Appl. Phys. Lett., 18, 4, pp. 127-128 (Feb., 1971)

2) H. Seki, T. Uchida and Y. Shibata: "Evaluation of Brightness and Contrast of Twisted-Nematic and Guest -Host Cells", Proc. SID, 25, 4, pp. 275-280 (1984)

3) C. H. Gooch and H. A. Tarrry: "Optical Characteristics of Twisted Nematic Liquid Crystal Films", Electron Lett., 10, 2, pp. 2-4 (June, 1974)

4) T. Nagatsuka, T. Shimomura and Y. Oishi : "Contrast Improvement by the Use of Polarizers for Liquid Crystal Displays", SID Symp. Digest., pp. 74-77 (1985)

5) K. Kinugawa, Y. Kando and M. Kanasaki : " $640 \times 400$ Pixel LCD Using Highly Twisted Birefringence Effect with Low Pretilt Angle", SID Symp. Digest, pp. 122-125 (1986)

6) T. J.Sheffer and J. Nehring: "Investigation of the Electro-Optical Properties of $270^{\circ}$ Chiral Nematic Layers in the Birefringence Mode", J. Appl. Phys., 58, 8, pp. 3022 -3031 (Oct., 1985)

7) M. Shadt and F. Leenhouts: "Electro-Optical Performance of a New, Black-White and Highly Multiplexable Liquid Crystal Display", Appl. Phys. Lett., 50, 5, pp. 236238 (Feb., 1987)

8) T. Uchida, H. Seki, C. Shishido and M. Wada: "Bright Dichroic Guest-Host LCDs without a Polarizer", Proc. SID, 22, 1, pp. 41-46 (1981)

9) D. L. White and G. N. Taylor: "New Absorptive Mode Reflective Liquid-Crystal Display Devices", J. Appl. Phys., 45, 11, pp. 4718-4723 (Nov., 1974)

10) G. H. Heilmeier and L. A. Zanoni: "Guest-Host Interaction in Nematic Liquid Crystals", Appl. Phys. Lett., 13, 3, pp. 91-91 (Aug., 1968)

11) H. Seki, T. Uchida and Y. Shibata: "Dichroic Dyes for Guest-Host Liquid-Crystal Cells", Japan. J. Appl. Phys., 24, 5, pp. 299-301 (May, 1985)

12) N. A. Clark and S. T. Lagerwall: "Submicrosecond Bis- table Electro-Optic Switching in Liquid Crystals", Appl. Phys. Lett., 36, 11, p. 899 (1980)

13) F. J. Kahn, P. N. Kendrichk, J. Leff and L. J. Linvoni : “A Paperless Plotter Display System Using a Laser Smectic Liquid-Crystal Light Valve”, SID Symp. Digest pp. 245257 (1987)

14) O. Myodo, K. Yagishita, M. Ohta and K. Kurahashi: "A Large Screen Color Display Using an Array of LCD Modules", Proc. Japan Display, pp. 430-432 (1983)

15) H. Matsukawa, Y. Wakahata and M. Ito: "A Continuous Very-Large-Area Liquid Crystal Color Display", SID Symp. Digest, pp. 58-61 (1985)

16) M.F. Schiekel and K. Fahrenschon: "Deformation of Nematic Liquid Crystals with Vertical Orientation in Electrical Fields", Appl. Phys. Lett., 19, 10, pp. 391-393 (Nov., 1971)

17) T. Uchida: "Multicolor Liquid Crystal Displays", Optical Eng., 23, 3, pp. 247-252 (June, 1984)

18) S. Takahashi, O. Shimokawa, H. Inoue, K. Uehara, T. Hirose and A. Kikuyama: "A Liquid Crystal Display Using Polymer Films", SID Symp. Digest, pp. 86-87 (1981)

19) J. L. Fergason, A. Dalisa, S. Lu and P. Prgaic, "Polymer Encapsulated Nematic Liquid Crystals for Use in High Resolution and Color Display", SID Symp. Digest, pp. 126 -127 (1986)

20) S. Aruga, R. Araki, H. Kamakura, J. Shinozaki and S. Morozumi : "High-Resolution Full-Color Video Projector with Poly-Si TFT Array Light Valves", SID Symp. Digest, pp. 75-78 (1987)

21) H. Hasebe and S. Kobayashi: "A Full-Color FieldSequential LCD using Modulated Backlight”, SID Symp. Digest, pp. 81-85 (1985)

22) T. Uchida : "A Liqid Crystal Multicolor Display using Color Filters", Proc. 1st European Display Res. Conf., pp. 39-42 (Sep., 1981) ; "A Full-Color Matrix Liquid Crystal Display with Color Layers on the Electrodes", IEEE Trans., ED-30, 5, pp. 503-507 (May, 1983)

23) T. Uchida, T. Katagishi, M. Onodera and Y. Shibata : "Reflective Multicolor Liquid-Crystal Display", IEEE Trans., ED-33, 8, pp. 1207-1211 (Aug., 1986); T. Koizumi and T. Uchida: "Bright Reflective Multicolor Liquid Crystal Display”, Proc. Eurodisplay '87, p. 131 (Sep., 1987)

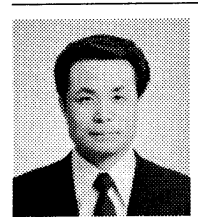

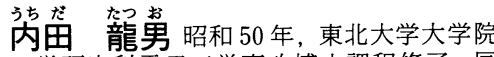
工学研究科電子工学専攻博士課程修了. 同 年, 東北大学工学部電子工学科助手. 現在, 同助教授. 液晶の基礎物性, ディスプレイデ バイス，オプトエレクトロニクスデバイス等 の研究に従事. 正会員. 